\title{
Mercantile Library forms partnership with University of Missouri-St. Louis
}

The st. Louis Mercantile Library has announced a partnership with the University of Missouri (UM)-St. Louis that would greatly increase public access, use, and visibility, as well as ensure the preservation of the Mercantile's historic collections and art treasures.

The Mercantile Libraty and all of its collections will move to the UM-St. Louis campus within the next two years. The Mercantile will be housed as a distinct entity in a wing of the Thomas Jefferson Library, the campus' main library.

Under the partnership agreement, UM-St. Louis will:

- renovate a 40,000-square-foot, two-story addition to the main library to house the Mercantile's collections;

- acquire additional research materials to update and build the core collections of the Mercantile;

- provide electronic conversion for the Mercantile's catalog records, giving access to its collections via UM's integrated online library system and worldwide via the Internet;

- provide technological and fiscal support for preservation and use of the Mercantile's collection;

- establish a Center for Transportation Studies, which will have close ties with the

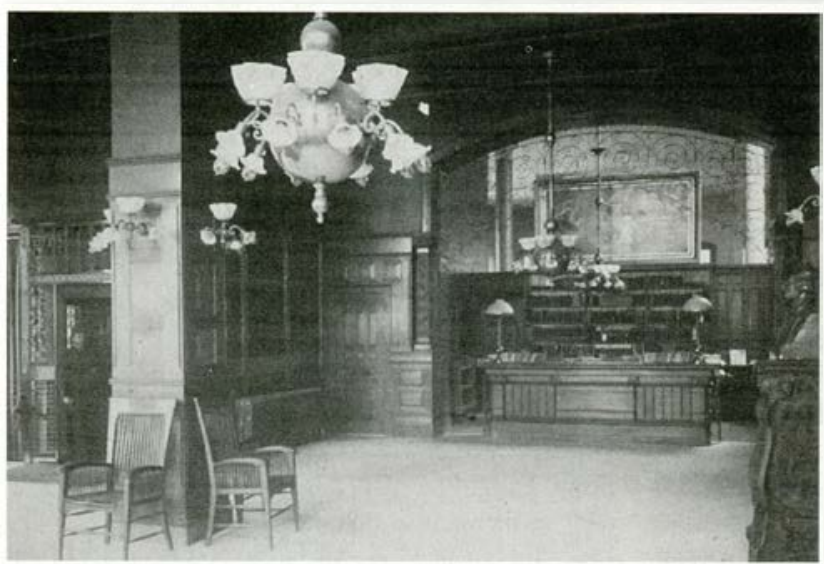

The Mercantile Library's current reading room as it appeared at the turn of the century. The art collections of the old building will be moved into new quarters at UM-St. Louis.
Mercantile's extensive Barriger Collection in railways and Pott Collection in inland waterways;

- link the collections and campus academic programs through faculty incentives and fellowships in areas of study which rely on the Mercantile's collections, particularly through increased support for the existing UMSt. Louis Center for the Humanities and the Center for Transportation Studies. In adidition, UM-St. Louis plans to establish up to two endowed professorships in areas related to the collections, using assets transferred from the association.

Founded 150 years ago, the Mercantile Library was the first library established west of the Mississippi and is the oldest cultural institution in St. Louls. It has been seeking opportunities to realize its vision of increasing use while preserving collections for about three years.

"After an extensive strategic planning effort, our board determined the best way to achieve our vision was through a partnership with another local educational or cultural institution," said Ruth Bryant, president of the Board. "After months of research and careful consideration, we selected UM-St. Louis because it provicled us with the greatest number of opportunities to increase use and preservation of our collection." UM-St. Louis chancellor Blanche $\mathrm{M}$. Touhill said, "As at historian and researcher, I have a deep love and respect for the Mercantile Library and its treasures.

In a related nove, the current executive director and chief librarian of the Mercantile Library, John Hoover, has been named associate clirector of libraries for special collections and director of the St. Louis Mercantile Library at the University of Missouri-St. Louis. All other Mercantile Library employees have also become employees of UM-St. Louis.-Jobn Hoover, Mercantile Library, and Joan Rapp, UM-St. Lou is 